\title{
A novel natural dye from Pseudomonas fluorescens imparts antibacterial finish and ultraviolet radiation resistance to textiles
}

See end of the paper for authors' affiliations Anupama Mishra Department of Home Science, Surajmal Agarwal Private Kanya Mahavidyalaya, Kumaun University, Kichha (Uttarakhand) India

Email : anupamamishra8@ gmail.com
ABSTRACT : The present study was taken up as an exploratory study to test if natural dye containing Pseudomonas fluorescens pigments may be used to develop protective clothing. This microbial dye was used to dye cotton, wool and silk fabrics and these fabrics were tested for antimicrobial finish against common human pathogens Escherichia coli and Staphylococcus aureus and their resistance to UV radiation. Wool samples exhibited best antimicrobial finish against E. coli while same was observed for silk samples against Staphylococcus aureus. Quantitatively, inhibition rate was highest for dyed wool samples $(23.77 \%$ and $49.47 \%)$ followed by silk (22.22\% and $42.55 \%)$ and cotton (16.17\% and $32.37 \%)$ for E. coli and Staphylococcus aureus, respectively. Among wool, silk and cotton fabrics, wool samples exhibited best UV protection factor. Study concluded that all the dyed samples exhibited antibacterial and UV protection properties. Textile materials with antibacterial finish may find use in preparation of sheets and gowns for hospital use and articles, which are less suitable for laundering such as mattresses and upholstery. UV protective textiles can be used in various apparels and accessories such as hats, shoes, umbrellas, baby-carrier covers, tents and beach cannabis etc.

KEY WORDS: Bacterial pigment, Natural dye, Antibacterial finish, Textiles, UV protection, Protective textiles

- HOW TO CITE THIS PAPER : Mishra, Anupama and Jahan, Shahnaz (2018). A novel natural dye from Pseudomonas fluorescens imparts antibacterial finish and ultraviolet radiation resistance to textiles. Asian J. Home Sci., 13 (1) : 321-327, DOI: 10.15740/HAS/AJHS/13.1/321-327. Copyright@ 2018: Hind AgriHorticultural Society. 